\title{
ESTIMATING EFFICIENCY IN AUTOMATIC MILKING SYSTEMS
}

\author{
Andrea Pezzuolo, Donato Cillis, Francesco Marinello, Luigi Sartori \\ University of Padova, Italy \\ andrea.pezzuolo@unipd.it
}

\begin{abstract}
Automatic Milking Systems (AMS), also known as robotic milking, are internationally accepted as a valid alternative to conventional milking parlour, and also as an advanced mean for dairy farm management. The continuous growth of labour and production costs are leading to the development of new improved AMS machines, especially for heaviest milking operations. Accordingly, AMS presence in European dairy farms is expected to continuously grow in the near future. AMS reduces heavy workload and allows milking frequency monitoring of each cow, based on its production level or lactation stage, without any additional labour cost. In this study, milking data of 15 dairy farms located in the Veneto region (North-Eastern Italy) were analyzed with the aim to estimate the Automatic Milking Systems performances, and eventually recognize operative limits and bottlenecks. Results are also of interest to allow definition of relations between the AMS capacity and milking time, which is useful to optimize operations and increase profitability. In particular, data relative to milk yield, daily milking sessions per cow, effective milking time, rejected milking time, cleaning time and machine downtime have been collected and used to evaluate the operative performance of each farm. Specifically, the analysis highlighted an average of $17 \mathrm{~h} \cdot$ day $^{-1}$ of milking activity, $5.6 \mathrm{~h} \cdot$ day $^{-1}$ of inactivity and $1.4 \mathrm{~h} \cdot \mathrm{day}^{-1}$ for cleaning and self-diagnosis. Additionally, $40 \%$ of the AMS reported the use for milking activities lower than $16 \mathrm{~h} \cdot$ day $^{-1}$ with idle periods exceeding in some cases $7-8 \mathrm{~h} \cdot$ day $^{-1}$.
\end{abstract}

Keywords: automatic milking system; efficiency; milking frequency; dairy housing system.

\section{Introduction}

Application of automatic technologies is a growing trend in agriculture $[1 ; 2]$ and in the livestock sector $[3 ; 4]$, and plays an active role in the future prospects [5;6]. The introduction of Automatic Milking Systems (AMS) is one of the most important technological changes in the dairy housing system [7], which can be considered not only as a substitute for milking parlors, but also as a new approach to manage dairy farms. Originally, the interest in this technology depended on the rising cost of labour, land, buildings and machinery combined with the decrease of milk prices [8; 9]. In fact, since 2009 about 8,000 farms have installed AMS [10], and nowadays they can be considered as a well-established technology. The main factors, which promote the introduction of AMS for dairy cows, are: improved work organization, increase in milk yields and improvement in animal behavior [11]. AMS reduces heavy-workload and allows milking frequency monitoring of each individual cow, based on its production level or lactation stage, without any additional labour costs [12]. Everything else remains unchanged, the cows milked more frequently during lactation, normally produce more milk than the cows milked twice a day [13]. Even if many factors can affect the behavior of dairy cows on a farm, the cows milked by AMS can carry out their daily activities with more freedom and have more interaction opportunities with their environment [14]. However, efficiency is one of the most important aspects of AMS evaluation; in fact, it can be estimated with the current operative and functional conditions [15]. The efficiency is the aim for many studies, in which the AMS evaluation is associated with its working capacity [16] and is expressed by the profitableness of automatic milking on dairy farms $[17 ; 18]$.

In this study, milking data of 15 dairy farms with AMS located in the Veneto region (NorthEastern Italy) were analyzed in order to evaluate the system performance according to the actual dairy organization. In detail, data about: milk yield, daily milking sessions per cow, effective milking time, rejected milking time, cleaning time and machine downtime have been collected and used to evaluate the operative performance of each farm.

\section{Materials and methods}

Milking data were collected during the year 2016 (January 2016 to December 2016) from 15 commercial dairy farms with AMS located in the Veneto region (North-Eastern Italy). The farms were characterized by a free-stall system, which houses $61 \pm 12$ lactation cows (mean \pm SD) and the prevalent breed was Holstein-Friesian. In each dairy farm, the same AMS model (single unit system) was available, with only negligible differences due to specific machine personalization (mainly in 
terms of data logging frequency, washing solution, dimensions of some components). The systems were positioned in the center of the stable and cows had free access to AMS all day long without selection gates or holding restraint areas (free cow traffic system). The cows were fed twice a day with a ration composed by cereal silage, maize flour, concentrate and hay. While concentrate was supplied from the automatic dispenser based on daily milk production data, provided by AMS, the remaining components were mixed to obtain a Total Mixed Ration (TMR). The data collected in all farms were used in order to recognize relationships between the AMS capacity and milking time. Factors associated with AMS efficiency evaluation were used to estimate other relations about the AMS application field, i.e. relation between percentage of on-time for milking, capacity and herd size and milking frequencies.

The following data were collected for each dairy farm taking advantage of the AMS management software.

- Milking performance: milk yield $\left(\mathrm{kg} \cdot\right.$ milking $\left.^{-1}\right)$; milking duration, i.e. the time between cow identification and the last teat-cup detachment (min. milking $\left.{ }^{-1}\right)$.

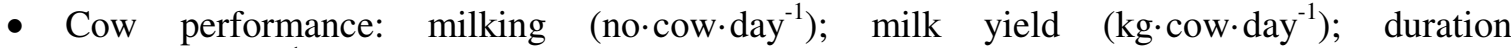
$\left(\min \cdot \operatorname{cow} \cdot\right.$ day $\left.^{-1}\right)$.

- AMS performance: milking $\left(\right.$ no $\cdot$ day $\left.^{-1}\right)$; milking duration $\left(\mathrm{h} \cdot \mathrm{day}^{-1}\right)$; idle time $\left(\mathrm{h} \cdot \mathrm{day}^{-1}\right)$; washing time $\left(\mathrm{h} \cdot \mathrm{day}^{-1}\right)$; milk yield $\left(\mathrm{kg} \cdot \mathrm{day}^{-1}\right)$; average milk flow rate $\left(\mathrm{kg} \cdot \mathrm{min}^{-1}\right)$.

\section{Results and discussion}

Table 1 shows the statistical data for the samples in the study. Overall, $53 \%$ of the dairy farms had a milking frequency $\geq 2.5$ times $\cdot$ day $^{-1}$ and $6,6 \%$ had a milking frequency $\leq 2.0$ times. day ${ }^{-1}$. The milking frequency of 2.4 milking. day ${ }^{-1}$ was the most common (20\% of cases).

These values are similar to those for milking cows, where the average milking frequency varied between 2.3 and $2.8[19 ; 20]$. The average milk production among the 15 farms resulted to be 1,947 $\mathrm{kg} \cdot$ AMS $\cdot$ day $^{-1}$ with production per head just over $30 \mathrm{~kg} \cdot \mathrm{day}^{-1}$.

Table 1

Performance of dairy cows in the 15 farms investigated

\begin{tabular}{|c|c|c|c|c|c|c|c|c|c|c|}
\hline \multirow[t]{2}{*}{$\begin{array}{l}\text { Dairy } \\
\text { Farm }\end{array}$} & \multicolumn{2}{|c|}{$\begin{array}{c}\text { Cow herd } \\
\text { size }\end{array}$} & \multicolumn{2}{|c|}{$\begin{array}{c}\text { Lactation } \\
\text { Cows }^{-} \text {AMS }^{-1}\end{array}$} & \multicolumn{2}{|c|}{ 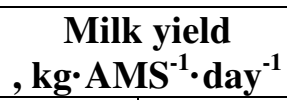 } & \multicolumn{2}{|c|}{$\begin{array}{c}\text { Milkings } \\
\text { no }^{\circ} \operatorname{cow}^{-1} \cdot \text { day }^{-1}\end{array}$} & \multicolumn{2}{|c|}{ 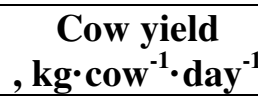 } \\
\hline & Min & Max & Mean & SD & Mean & SD & Mean & SD & Mean & SD \\
\hline A & 47 & 57 & 51 & 2.6 & 1,841 & 171 & 2.8 & 0.2 & 36.0 & 2.3 \\
\hline B & 55 & 64 & 61 & 1.4 & 1,917 & 167 & 2.8 & 0.3 & 31.2 & 2.6 \\
\hline $\mathrm{C}$ & 71 & 84 & 82 & 6.9 & 2,401 & 256 & 2.1 & 0.2 & 26.0 & 2.5 \\
\hline $\mathrm{D}$ & 55 & 72 & 66 & 3.5 & 2,506 & 121 & 2.5 & 0.2 & 37.5 & 1.9 \\
\hline $\mathrm{E}$ & 53 & 61 & 59 & 1.4 & 1,590 & 257 & 2.7 & 0.4 & 26.6 & 4.1 \\
\hline $\mathrm{F}$ & 47 & 69 & 57 & 3.0 & 2,217 & 173 & 2.9 & 0.2 & 39.7 & 3.0 \\
\hline G & 57 & 67 & 64 & 2.2 & 1,760 & 327 & 2.4 & 0.3 & 27.4 & 2.7 \\
\hline $\mathrm{H}$ & 46 & 69 & 58 & 3.6 & 1,626 & 101 & 2.6 & 0.2 & 27.7 & 1.7 \\
\hline I & 31 & 45 & 38 & 4.8 & 1,375 & 291 & 3.0 & 0.2 & 35.7 & 4.3 \\
\hline $\mathrm{L}$ & 51 & 64 & 59 & 3.0 & 1,941 & 235 & 2.5 & 0.3 & 32.5 & 3.9 \\
\hline $\mathrm{M}$ & 40 & 60 & 48 & 5.7 & 1,542 & 148 & 2.6 & 0.2 & 31.8 & 3.4 \\
\hline $\mathrm{N}$ & 66 & 75 & 70 & 3.0 & 2,376 & 150 & 2.4 & 0.2 & 33.8 & 2.1 \\
\hline $\mathrm{O}$ & 70 & 78 & 74 & 1.6 & 2,672 & 167 & 2.4 & 0.1 & 35.9 & 2.0 \\
\hline $\mathrm{P}$ & 47 & 53 & 49 & 1.4 & 1,786 & 121 & 3.3 & 0.3 & 36.2 & 2.6 \\
\hline $\mathrm{Q}$ & 58 & 84 & 76 & 8.0 & 1,661 & 350 & 1.7 & 0.2 & 21.5 & 2.9 \\
\hline Mean & $\begin{array}{l}52.9 \\
\end{array}$ & "66.8 & $\overline{660.8}$ & 3.47 & $1,1,947$ & 202 & 2.6 & 0.23 & 31.97 & 2.80 \\
\hline SD & 10.8 & 11.0 & 11.7 & - & 394 & - & 0.4 & - & 5.15 & - \\
\hline
\end{tabular}

By the analysis of the operative time of the milking robot in the 15 farms (Table 2) each AMS presents on average: $17 \mathrm{~h} \cdot$ day $^{-1}$ of milking activity, $5.6 \mathrm{~h} \cdot$ day $^{-1}$ of inactivity while $1.4 \mathrm{~h} \cdot$ day $^{-1}$ for 
cleaning and self-diagnosis. However, $40 \%$ of the AMS presented a use for milking activities under $16 \mathrm{~h} \cdot$ day $^{-1}$ with idle periods that sometimes even exceed 7-8 h. day ${ }^{-1}$ (Fig. 1).

Milking time per cow resulted of $6.6 \mathrm{~min} \cdot \mathrm{cow}^{-1}$ with an average milk flow rate of $4.9 \mathrm{~kg} \cdot \mathrm{min}^{-1}$. Only $13 \%$ of the dairy farms have presented a milking time longer than $8 \mathrm{~min} \cdot \mathrm{cow}^{-1}$.

From the analysis of the chronological accesses to AMS, it is possible to obtain important information on performance. In fact, as we can see from Tab. 3, the average number of milking sessions in the farms has proven to be equal to 156 . Almost irrelevant in terms of time were the fail milkings, while the rejected ones $\left(83 \cdot \mathrm{AMS}^{-1} \cdot \mathrm{day}^{-1}\right)$ are an important share, which will certainly go to impact on the performance and indirectly also on the operative availability of the AMS.

On average the share of accesses with the next milking session represents $65 \%$ of the AMS operations (Fig. 2), while the share of rejected ones amounted to $33.8 \%$ of total AMS utilization time. Not particularly significant is the share of fail milkings $(1.1 \%)$.

Table 2

Analysis of AMS performance in the 15 farms investigated

\begin{tabular}{|c|c|c|c|c|c|c|c|c|}
\hline \multirow[t]{2}{*}{$\begin{array}{l}\text { Dairy } \\
\text { Farm }\end{array}$} & \multicolumn{2}{|c|}{$\begin{array}{l}\text { Milking time } \\
\text { h·AMS }{ }^{-1} \cdot \text { day }^{-1}\end{array}$} & \multicolumn{2}{|c|}{$\begin{array}{c}\text { Idle time } \\
, \mathbf{h} \cdot \mathrm{AMS}^{-1} \cdot \text { day }^{-1}\end{array}$} & \multicolumn{2}{|c|}{$\begin{array}{l}\text { Washing time } \\
\text {, h·AMS }{ }^{-1} \cdot \text { day }^{-1}\end{array}$} & \multirow{2}{*}{$\begin{array}{c}\begin{array}{c}\text { Milking time } \\
\text { min }^{-\operatorname{cow}^{-1}}\end{array} \\
\text { Mean }\end{array}$} & \multirow{2}{*}{$\begin{array}{c}\begin{array}{c}\text { Average milk } \\
\text { flow rate } \\
\text { kg· } \text { min }^{-1}\end{array} \\
\text { Mean }\end{array}$} \\
\hline & Mean & $\mathrm{SD}$ & Mean & SD & Mean & $\mathrm{SD}$ & & \\
\hline $\bar{A}$ & 15.4 & 0.05 & 7.4 & 0.05 & 1.2 & 0.05 & 6.5 & 5.6 \\
\hline B & 16.9 & 0.06 & 6.1 & 0.07 & 1.1 & 0.07 & 6.0 & 5.2 \\
\hline $\mathrm{C}$ & 20.1 & 0.09 & 2.2 & 0.10 & 1.7 & 0.10 & 7.1 & 3.6 \\
\hline D & 20.2 & 0.05 & 2.8 & 0.04 & 1.0 & 0.05 & 7.2 & 5.2 \\
\hline $\mathrm{E}$ & 12.4 & 0.12 & 9.1 & 0.13 & 2.5 & 0.13 & 4.7 & 5.7 \\
\hline $\mathrm{F}$ & 18.3 & 0.05 & 4.2 & 0.05 & 1.5 & 0.05 & 6.7 & 5.9 \\
\hline $\mathrm{G}$ & 18.2 & 0.08 & 4.1 & 0.09 & 1.7 & 0.09 & 7.0 & 3.9 \\
\hline $\mathrm{H}$ & 17.5 & 0.04 & 5.4 & 0.05 & 1.1 & 0.05 & 6.9 & 4.0 \\
\hline I & 15.9 & 0.10 & 7.0 & 0.10 & 1.1 & 0.10 & 8.3 & 4.3 \\
\hline $\mathrm{L}$ & 12.3 & 0.08 & 10.5 & 0.09 & 1.2 & 0.09 & 5.1 & 6.4 \\
\hline $\mathrm{M}$ & 17.5 & 0.06 & 5.1 & 0.06 & 1.4 & 0.06 & 8.4 & 3.8 \\
\hline $\mathrm{N}$ & 15.1 & 0.05 & 7.3 & 0.06 & 1.6 & 0.06 & 5.4 & 6.3 \\
\hline $\mathrm{O}$ & 18.6 & 0.04 & 3.8 & 0.04 & 1.6 & 0.04 & 6.2 & 5.8 \\
\hline $\mathrm{P}$ & 20.6 & 0.04 & 2.6 & 0.05 & 0.8 & 0.05 & 7.6 & 4.7 \\
\hline $\mathrm{Q}$ & 15.2 & 0.10 & 6.5 & 0.10 & 2.3 & 0.10 & 6.9 & 3.1 \\
\hline Mean & 16.95 & 0.07 & 5.61 & 0.07 & 1.45 & 0.07 & 6.67 & 4.90 \\
\hline SD & 2.58 & - & 2.41 & - & 0.47 & 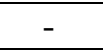 & 1.06 & 1.06 \\
\hline
\end{tabular}

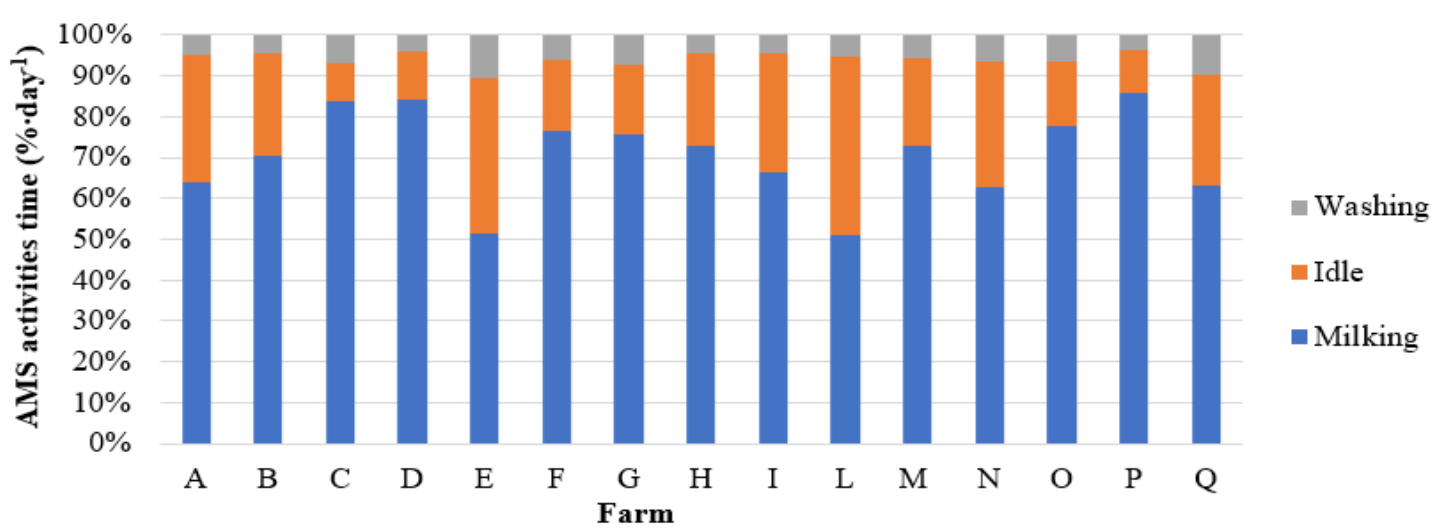

Fig. 1. Distribution of the 3 main AMS activities time during 24 hours (A) 


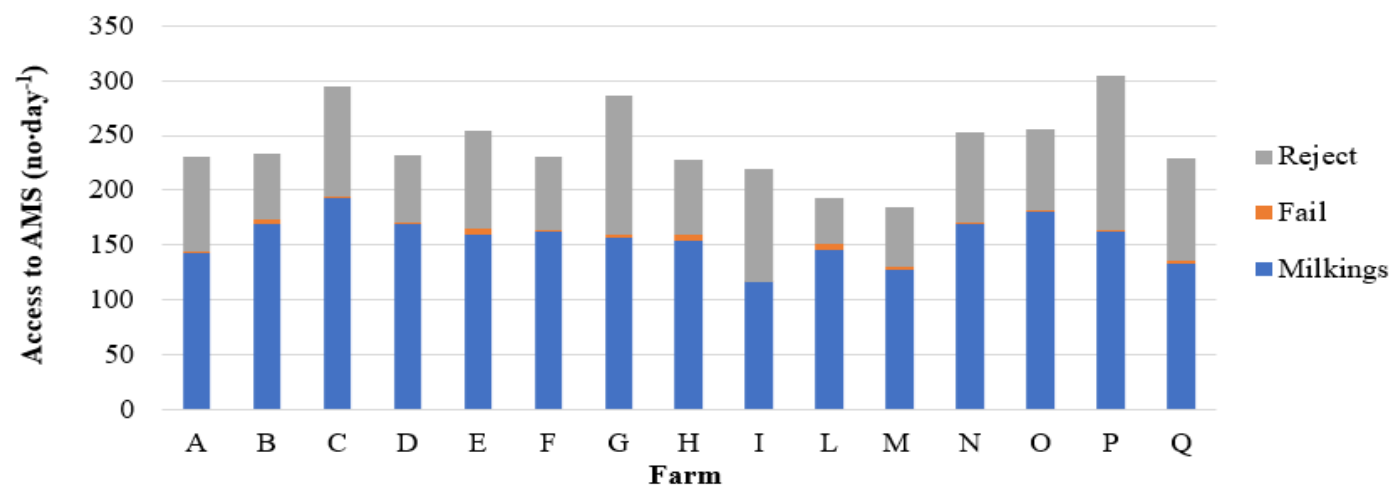

Fig. 2. Average daily accesses in the 15 AMS farms investigated

Table 3

Average daily values of milkings, fail milkings and reject for AMS

\begin{tabular}{|c|c|c|c|c|c|c|c|c|c|}
\hline \multirow[t]{2}{*}{\begin{tabular}{|l} 
Dairy \\
Farm \\
\end{tabular}} & \multicolumn{2}{|c|}{$\begin{array}{c}\text { Milkings, } \\
\text { no }^{*} \text { AMS }^{-1} \cdot \text { day }^{-1}\end{array}$} & \multicolumn{2}{|c|}{$\begin{array}{l}\text { Fail milkings, } \\
\text { no } \text { AMS }^{-1} \cdot \text { day }^{-1}\end{array}$} & \multicolumn{2}{|c|}{$\begin{array}{c}\text { Reject, } \\
\text { no } \cdot \text { AMS }^{-1} \cdot \text { day }^{-1}\end{array}$} & \multirow{2}{*}{$\begin{array}{c}\begin{array}{c}\text { Milkings, } \\
\text { \% of time }\end{array} \\
\text { Mean } \\
\end{array}$} & \multirow{2}{*}{$\begin{array}{c}\begin{array}{c}\text { Fail milkings } \\
\text { \% of time }\end{array} \\
\text { Mean } \\
\end{array}$} & \multirow{2}{*}{$\begin{array}{c}\begin{array}{c}\text { Reject, } \\
\% \text { of time }\end{array} \\
\text { Mean }\end{array}$} \\
\hline & Mean & SD & Mean & SD & Mean & SD & & & \\
\hline $\mathrm{A}$ & 143 & 12.3 & 2 & 0.05 & 86 & 0.05 & 61.9 & 0.9 & 37.2 \\
\hline B & 170 & 15.3 & 4 & 0.07 & 60 & 0.07 & 72.6 & 1.7 & 25.6 \\
\hline $\mathrm{C}$ & 193 & 21.6 & 1 & 0.10 & 100 & 0.10 & 65.6 & 0.3 & 34.0 \\
\hline $\mathrm{D}$ & 169 & 9.0 & 2 & 0.04 & 61 & 0.05 & 72.8 & 0.9 & 26.3 \\
\hline $\mathrm{E}$ & 160 & 29.3 & 5 & 0.13 & 89 & 0.13 & 63.0 & 2.0 & 35.0 \\
\hline $\mathrm{F}$ & 162 & 25.9 & 2 & 0.05 & 66 & 0.05 & 70.4 & 0.9 & 28.7 \\
\hline $\mathrm{G}$ & 157 & 12.1 & 2 & 0.09 & 127 & 0.09 & 54.9 & 0.7 & 44.4 \\
\hline $\mathrm{H}$ & 154 & 18.1 & 5 & 0.05 & 69 & 0.05 & 67.5 & 2.2 & 30.3 \\
\hline I & 116 & 13.2 & 1 & 0.10 & 103 & 0.10 & 52.7 & 0.5 & 46.8 \\
\hline $\mathrm{L}$ & 146 & 18.4 & 5 & 0.09 & 42 & 0.09 & 75.6 & 2.6 & 21.8 \\
\hline $\mathrm{M}$ & 127 & 16.3 & 3 & 0.06 & 55 & 0.06 & 68.6 & 1.6 & 29.7 \\
\hline $\mathrm{N}$ & 169 & 14.3 & 2 & 0.06 & 82 & 0.06 & 66.8 & 0.8 & 32.4 \\
\hline $\mathrm{O}$ & 180 & 13.3 & 2 & 0.04 & 74 & 0.04 & 70.3 & 0.8 & 28.9 \\
\hline $\mathrm{P}$ & 162 & 6.3 & 2 & 0.05 & 140 & 0.05 & 53.3 & 0.7 & 46.1 \\
\hline $\mathrm{Q}$ & 133 & 11.8 & 3 & 0.10 & 93 & 0.10 & 58.1 & 1.3 & 40.6 \\
\hline Mean & 156.1 & 15.81 & 2.7 & 0.07 & 83.1 & 0.07 & 64.94 & 1.19 & 33.85 \\
\hline SD & 20.4 & - & 1.4 & - & 26.8 & - & 7.38 & - & 7.75 \\
\hline
\end{tabular}

The comparison of average AMS performance per cow (Fig. 3) shows that, on a daily basis, the share of milking sessions per cow is 2.62 , the one of fail milkings is 0.05 , while the one of reject is 1.43. However, the correct management of this last important operative parameter results important in order to increase the share of the AMS productivity.

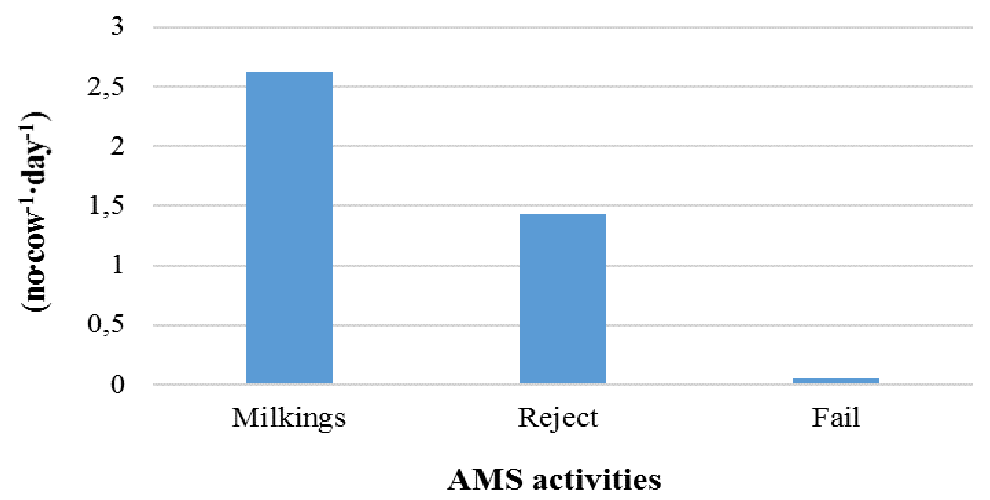

Fig. 3. Number of daily milkings, reject and fail per cow 
The result of the current observations becomes part of the general discussion about the efficiency of AMS. Milking frequency of the cow is quoted as one of the most important factors, which express profits gained from the AMS operation at dairy farms. However, practical utilization of the automated milking systems covers only a $65-85 \%$ of the working time due to connection failures, cleaning down times and other technical problems [21]. This suggests that it is reasonable to expect that on an average day, only 19 of the 24 hours are available for successful milkings. Achievement of higher occupancy rates (ideally $100 \%$ ) have to include consideration on the technical aspects of the implemented machines, but are not limited to that: indeed, other aspects have also to be considered, mainly related to the feeding strategy, cow behavior and cow traffic.

The analysis of the collected data in all farms has allowed to find a relation between the AMS capacity and the milking time; in fact, an effect of the cow herd size was found on the milking frequency in 15 farms that actively use AMS. According to Fig. 4 it is possible to indicate a decrease in the milking frequency when the herd size operated by AMS is increasing. However, increase in the number of milkings per cow does not necessarily mean a superior milk yield per AMS unit [22; 23].

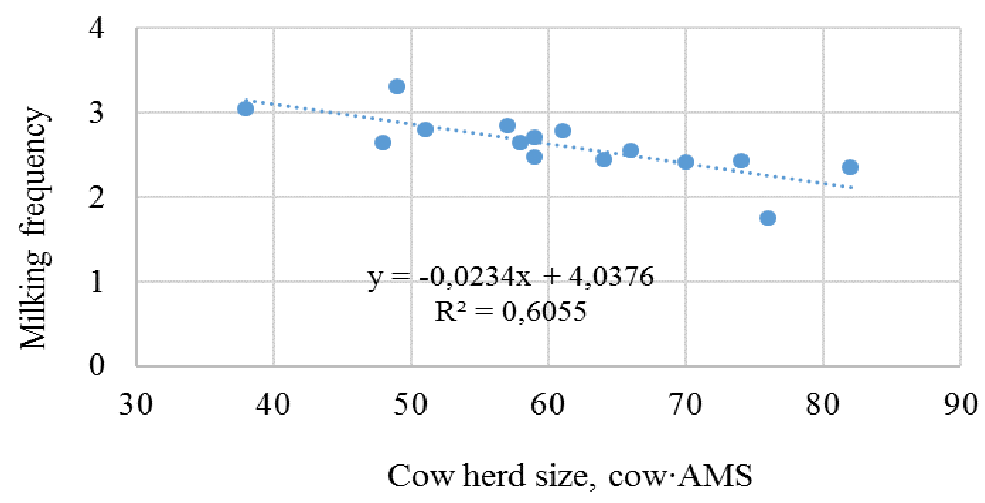

Fig. 4. Relation between the milking frequency and the cow herd size

\section{Conclusions}

In the current study, milking data of 15 dairy farms with AMS located in Veneto region (NorthEastern Italy) were analysed, in order to estimate the system capacity in each farm under actual dairy organization.

1. Notwithstanding the number of the daily milkings examined, it is in line with the studies existing in literature, which positively influence $65 \%$ of daily operative time, the management of "reject" is very important that actually makes AMS unproductive for almost $34 \%$ of the day.

2. This last parameter, while it may represent an important key to adapt the animals to the new milking routine, on the other hand, if such system is not carefully handled, could reduce the performance of the AMS.

3. However, many other management factors, such as the feeding strategy, cow traffic, stable layout and the cow herd size, may potentially influence the operative performance of the AMS.

\section{References}

1. Marinello F., Pezzuolo A., Gasparini F., Arvidsson J., Sartori L., Application of the Kinect sensor for dynamic soil surface characterization. Precision Agriculture, vol. 5, 2015, pp. 1-12.

2. Pezzuolo A., Dumont B., Sartori L., Marinello F., De Antoni Migliorati M., Basso B. Evaluating the impact of soil conservation measures on soil organic carbon at the farm scale. Comput. Electron. Agric vol. 135, 2017, pp. 175-182.

3. Unal H., Kuraloglu H., Determination of operating parameters in milking robots with free cow traffic. Engineering for Rural Development, vol. 14, 2015, pp. 234-240.

4. Nydegger F., Grothmann A. Automatic feeding of cattle: results of a survey on the state of the art. ART-Berichte, vol. 710, 2009, pp. 8.

5. Basso B., Dumont B., Cammarano D., Pezzuolo A., Marinello F., Sartori L. Environmental and economic benefits of variable rate nitrogen fertilization in a nitrate vulnerable zone. Science of the total environment, vol. 545-546, 2016, pp. 227-235. 
6. Boscaro D., Pezzuolo A., Grigolato S., Cavalli R., Marinello F., Sartori L. Preliminary analysis on mowing and harvesting grass along riverbanks for the supply of anaerobic digestion plants in north-eastern Italy. Journal of Agricultural Engineering, vol. 46, 2015, pp. 100-104.

7. Da Borso F., Chiumenti A., Sigura M., Pezzuolo A. Influence of automatic feeding systems on design and management of dairy farms. Journal of Agricultural Engineering, 2017, in press. DOI: $10.4081 /$ jae.2017.642

8. de Koning K., van der Vost Y., Meijering A. Automatic milking experience and development in Europe. Wageningen Academic Publishers, Wageningen, the Netherlands, 2002, pp. 1-11.

9. Svennersten-Sjaunja K. M., Pettersson G. Pros and cons of automatic milking in Europe. J. Anim. Sci., vol. 86, 2007, pp. 37-46.

10. de Koning K. Automatic milking - Common practice on dairy farms in Proc. Second North Am. Conf. Robotic Milking, Toronto, Canada. Precision Dairy Operators, Elora, ON, Canada, 2010, pp. 59-63.

11. Hogeveen H., Ouweltjes W, de Koning C.J.A.M., Stelwagen K. Milking interval, milk production and milk flowrate in an automatic milking system. Livest. Prod. Sci., vol. 72, 2001, pp. 157-167.

12. Jacobs J.A., Siegford J.M. Invited review: The impact of automatic milking systems on dairy cow management, behavior, health, and welfare. J. Dairy Sci., vol. 95, 2012, pp. 2227-2247.

13. Wright J.B., Wall E.H., McFadden T.B. Effects of increased milking frequency during early lactation on milk yield and udder health of primiparous Holstein heifers. J. Anim. Sci., vol. 91, 2013, pp. 195-202.

14. Stelwagen K., Phyn C.V., Davis S.R., Guinard-Flament J., Pomiès D., Roche J.R., Kay J.K. Reduced milking frequency: Milk production and management implications. J. Dairy Sci., vol. 96, 2013, pp. 3401-3413.

15. Laurs A., Priekulis J., Purinš M. Studies of operating parameters in milking robots. In: 8th International Scientific Conference on Engineering for Rural Development. Latvia University of Agriculture, Jelgava, Proceedings, vol. 8, 2009, pp. 38-42.

16. Artmann R. System capacity of single box AMS and effect on the milk performance. Wageningen Academic Publishers, Wageningen, the Netherlands, 2004, pp. 474-475.

17. Cooper K., Parsons D.J. An economic analysis of automatic milking using a simulation model. Journal of Agricultural Engineering Research, vol. 73, 1999, pp. 311-321.

18. Bijl R., Kooistra S.R., Hogeveen H. 2007. The profitability of automatic milking on Dutch dairy farms. Journal of Dairy Science, vol. 90, 2007, pp. 239-248.

19. de Koning K., Ouweltjes W. Maximising the milking capacity of an automatic milking system. Wageningen Academic Publishers, Wageningen, the Netherlands, 2000, pp. 38-46.

20. Bach A., Devant M., Iglesias C., Ferrer A. Forced traffic in automatic milking systems effectively reduces the need to get cows. Journal of Dairy Science, vol. 92, 2009, pp. 1272-1280.

21. Halachmi I. Design methodology for the robot milk barn: modelling, simulating, validating and optimization. Thesis. Wageningen University. 1999, ISBN-90-8508-130-3.

22. Castro A., Pereira J.M., Amiama C., Bueno J. Estimating efficiency in automatic milking systems. Journal of Dairy Science, vol. 95, 2012, pp. 929-936.

23. Gaworski M., Leola A., Sada O., Kic P., Prikulis J. Effect of cow traffic and herd size on cow performance and automatic milking systems capacity. Agronomy Research, vol. 14, 2016, 33-40. 